\title{
R\&D protection from GATT rules 'should be abolished'
}

\begin{abstract}
Washington. Subsidies for research and development could be vulnerable to legal challenge if governments change their international trade agreement in line with a recommendation from an international study endorsed by the US National Research Council (NRC).
\end{abstract}

The study says governments should drop provisions in the General Agreement on Tariffs and Trade (GATT) that protect such subsidies from charges of being an unfair trade practice.

The current exemptions allow governments in the United States, Japan and Europe to support large technology programmes, free from the threat of a challenge under GATT rules. But the study says that these exemptions encourage other countries to press for exemptions for other forms of spending, such as environmental subsidies.

Its authors warn that the exemptions are ill-defined and likely to encourage abuse by governments that want to circumvent the spirit of the agreement. But their conclusions are already being contested by US administration officials, who claim that the exemptions are needed to protect government-industry collaboration.

The NRC is the operating arm of the National Academy of Sciences and the

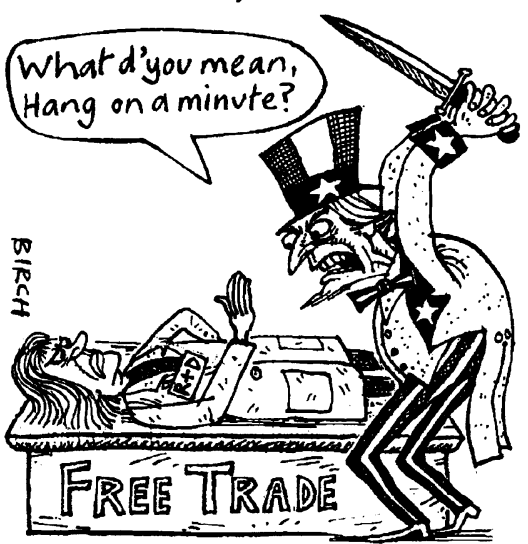

National Academy of Engineering, and is the body on which the federal government relies most heavily for advice on science and technology matters.

Its advice is rarely disputed by government officials in public. But representatives of the US Commerce Department - which launched the drive for the exemptions during the 'Uruguay round' of trade negotiations - immediately attacked this NRC finding in unusually direct terms.

Mark Bohannon, chief attorney in the office of Mary Good, the under-secretary for commerce, told the NRC panel at a public meeting on 17 October that he "regretted very much" its finding, predicting it would divert attention from the rest of the report.
Bohannon said he did not think there was a good argument to support its finding. "The origin of the special treatment was the reality that the United States invested more than any other nation in R\&D infrastructure," he said. The provision was therefore needed so that corporations "would not be harmed by their cooperation with the government" in various $R \& D$ programmes.

The "special treatment" drawn up during the GATT negotiations allows corporations to receive from government sources up to three-quarters of basic research costs, half of applied research costs and one-quarter of development costs, without any danger of a subsidy complaint being accepted by the World Trade Organization, the body set up to administer GATT.

But according to Alan Wolff, a lawyer and co-chair of the international panel that oversaw the study, the special treatment is not needed to protect governmentsponsored R\&D, and undermines GATT by opening the way to other exemptions.

"Experience indicates that R\&D subsidies are rarely the subject of countermeasures because they do not cause harm" to competitors, says Wolff. "We feel that government support for $\mathrm{R} \& \mathrm{D}$ is a good thing but, if injury is caused, that subsidy should be actionable" like any other.

Wolff admits that the R\&D exemption could not be removed immediately. But he says this should happen when the GATT agreement is reviewed after five years.

Charles Wessner, the staff director of the study, says that the United States negotiated the R\&D exemption in GATT hurriedly, after its negotiators had discovered that earlier versions of the agreement "outlawed our own practices" of research support. The US negotiators "got down a cul-de-sac and couldn't find a way out", he says.

The 200-page study - Conflict and Cooperation in National Competition for HighTechnology Industry - was conducted jointly by the NRC's board on Science, Technology and Economic Policy and two German research institutions, the Hamburg Institute for Economic Research and the Kiel Institute for World Economics. It was paid for by the German-American Academic Council and ten corporate sponsors, and supervised by a panel of economists, academics and industrialists from six countries.

The study finding highlights a significant contradiction in the trade policies of Europe and the United States. Both are publicly committed to free trade in high-technology goods and services, but wish to pursue technology policies that inject billions of dollars of public money into industrial research each year.

\section{India faces US trade action over failure to amend patent law}

New Delhi. An Indo-US dispute over patents, raised by the Clinton administration before the World Trade Organization (WTO), is likely to take a decisive turn in the next few weeks after the failure of attempts at a resolution.

The United States is now considering third-party adjudication. The dispute centres on India's failure to bring its patent law into line with WTO's Trade Related Intellectual Property Rights Agreement (TRIPs). The adjudicators' decision, which could include trade penalties against India, would be binding.

Both India and the United States are members of WTO. Under TRIPs, India is obliged to allow the patenting of food and pharmaceuticals, which are excluded from the 1970 Patents Act. The agreement also includes provisions with effect from 1 January 1995 for the 'black-box' facility of lodging product patent applications. The United States has also alleged that, as a signatory of TRIPs, India must agree to provide "exclusive marketing rights" for product patent applicants.

The Indian government, faced with cross-party opposition to proposed amendments to the Patents Act, has been unable to comply with US demands. An amended version of the act, though passed in 1995 by the Lokh Sabha, the lower house of parliament, remains blocked in Rajya Sabha, the upper house.

When the previous Congress party government signed the TRIPs agreement, many politicians expressed reservations about the implications for the prices and availability of vital products, such as medicines and seeds. Matters have not been helped by the filing by US companies for patents on products found in India, including one on a process involving the active ingredient of neem (see Nature 377, 95; 1995). But government officials are conscious of the potential damage to trade if India is penalized for not complying with TRIPs.

Sixty days of 'mutual consultations' between the two countries, prescribed under WTO dispute procedures, ended in Geneva last month without result. This opens the way for the United States to ask WTO to take the case to a panel of international adjudicators.

Indian officials are bracing themselves for further US pressure through WTO. "If the United States decides to ask for the WTO dispute settlement panel, the implications could be disastrous for India's international trade," says one official.

K. S. Jayaraman 